\title{
ABSTRAK \\ STUDI KASUS PADA PASIEN GERONTIK Tn. "S"' DENGAN RHEUMATIK ARTRITIS DIPUSKESMAS BAROMBONG KECAMATAN TAMALATE KOTA MAKASSAR
}

\author{
*Maria Sumaryati* \\ Nidk;8854470018 \\ Mariasumaryati11@gmail.com \\ Dosen tetap program studi DIII Keperawatan Sandi Karsa Makassar
}

Perilaku masyarakat Indonesia Sehat 2020 adalah perilaku proaktif untuk memelihara dan meningkatkan kesehatan, mencegah terjadinya resiko terjadinya masalah kesehatan, melindungi diri dari ancaman masalah kesehatan serta berpartisipasi aktif dalam gerakan kesehatan masyarakat.

Tujuan penelitian memperoleh gambaran secara umum tentang pelaksanaan Studi kasus pada Pasien Gerontik Tn."S” dengan Rheumatik Artritis di Puskesmas Barombong Kelurahan Barombong Kota Makassar. Metode penelitian menggunakan metode penelitian studi kasus dengan pendekatan proses keperawatan

Hasil penelitian Pada pengkajian dengan rheumatik data yang ditemukan dalam tinjauan teori tidak ditemukan pada kasus yaitu : mual, sianosis, pembengkakan pada sendi, kesemutan pada tangan dan kaki, hilangnya sensasi pada jari tangan dan kaki, hilangnya sensasi pada jari tangan, pembengkakan pada sendi, isolasi, Diagnosa keperawatan yang ditemukan dalam kasus ada yang tidak terdapat pada teori, Risiko cedera fisik b/d penurunan fungsi tubuh., Pelaksanaan rencana asuhan keperawatan mencakup pada masalah keperawatan, yang muncul dengan berpedoman pada teori dan tetap memperhatikan kondisi pasien, fasilitas yang ada dan kebijaksanaan pihak Puskesmas Barombong Kecamatan Tamalate Kota Makassar, Pada evaluasi keperawatan masalah Tn."S" belum ada yang teratasi karena pasien masih mengeluh nyeri pada persendian dan masih terjadi kekakuan pada tulang dan sendi.

Saran pendidikan dan penyuluhan kesehatan perlu ditingkatkan dan dilaksanakan secara intensif pada seluruh komponen masyarakat, terutama pada usia lanjut karena sangat rentang terhadap berbagai jenis penyakit dalam hal ini penyakit Rheumatik, agar mereka dapat berperan aktif untuk memelihara dan meningkatkan derajat kesehatannya, Rencana keperawatan yang telah dilaksanakan agar tetap menjadi program bagi keluarga Tn."S" dan mempertahankan apa yang telah didapatkan selama pelaksanaan asuhan keperawatan. Dalam pelaksanaan tindakan keperawatan hendaknya disesuaikan dengan situasi dan kondisi yang dimiliki oleh lansia.

Kaka kunci: Pasien Gerontik, Artritis Rhemaotid

\section{Pendahuluan}

Gambaran keadaan masyarakat Indonesia di masa depan atau visi yang ingin dicapai melalui pembangunan kesehatan tersebut dirumuskan sebagai Indonesia sehat 2020. Perilaku masyarakat Indonesia Sehat 2020 adalah perilaku proaktif untuk memelihara dan meningkatkan kesehatan, mencegah terjadinya resiko terjadinya masalah kesehatan, melindungi diri dari ancaman masalah kesehatan serta berpartisipasi aktif dalam gerakan kesehatan masyarakat. (Depkes 2000)

Peningkatan jumlah lansia tidak terlepas dari keberhasilan pembangunan nasional Indonesia. Keberhasilan itu dapat dilihat dari adanya peningkatan kesejahteraan rakyat dan kemajuan di bidang teknologi. Peningkatan kesejahteraan rakyat meliputi peningkatan status ekonomi, pendidikan dan kesehatan. Kemajuan di bidang teknologi khusus teknologi bidang kedokteran memungkinkan ditemukannya peralatan untuk diagnosis dan terapi, obat-obatan, vaksin dan teknologi pengolahan pangan/nutrisi yang berkualitas. Hal itu mengakibatkan perubahan pola masalah kesehatan dari masalah kesehatan infeksi ke masalah kesehatan degenerasi dan kardiovaskuler, penurunan angka kematian bayi dan peningkatan umur harapan hidup
Lansia bukan suatu masalah kesehatan, namun merupakan tahap lanjut dari proses kehidupan yang ditandai dengan penurunan kemampuan tubuh untuk berdaptasi dengan stres lingkungan. Penurunan kemampuan berbagai organ, fungsi dan sstem tubuh itu bersifat alamiah/fisiologis.

\section{Tinjauan Teori}

\section{Konsep Dasar Lansia}

Lanjut usia merupakan istilah tahap akhir dari proses penuaan. Dalam mendefinisikan batasan penduduk lanjut usia menurut Badan Koordinasi Keluarga Berencana Nasional ada tiga aspek yang perlu dipertimbangkan yaitu aspek biologi, aspek ekonomi dan aspek sosial (BKKBN 1998). Secara biologis penduduk lanjut usia adalah penduduk yang mengalami proses penuaan secara terus menerus, yang ditandai dengan menurunnya daya tahan fisik yaitu semakin rentannya terhadap serangan penyakit yang dapat menyebabkan kematian. Hal ini disebabkan terjadinya perubahan dalam struktur dan fungsi sel, jaringan, serta sistem organ. Secara ekonomi, penduduk lanjut usia lebih dipandang sebagai beban dari pada sebagai sumber daya. 
Banyak orang beranggapan bahwa kehidupan masa tua tidak lagi memberikan banyak manfaat, bahkan ada yang sampai beranggapan bahwa kehidupan masa tua, seringkali dipersepsikan secara negatif sebagai beban keluarga dan masyarakat (Suhartini, 2001).

Pertambahan penduduk orang usia lanjut di Negara maju seperti Amerika Serikat adalah kurang lebih 1.000 orang per hari pada tahun 1985 dan diperkirakan $50 \%$ dari penduduk berusia di atas 50 tahun, sehingga istilah Baby Boom pada masa lalu berganti menjadi "ledakan penduduk lanjut usia" (Lansia).

Ditinjau secara Demografi, menurut sensus penduduk pada tahun 1980, di Indonesia jumlah penduduk 147,3 juta. Dari angka tersebut terdapat 16,3 juta orang $(11 \%)$ orang yang berusia 50 tahun ke atas dan kurang lebih 6,3 juta orang (4,3\%) berusia $60 \mathrm{ke}$ atas. Dari 6,3 juta orang lansia terdapat $822.831(13,06$ $\%$ ) orang yang tergolong jompo, yaitu para lanjut usia yang memerlukan bantuan khusus sesuai dengan undang-undang bahkan mereka harus dipelihara oleh Negara.

Pada tahun 2000 diperkirakan jumlah lanjut usia meningkat menjadi 9,99 \% dari seluruh penduduk Indonesia (22,277.700 jiwa) dengan umur harapan hidup 65 - 70 tahun dan pada tahun 2020 akan diperkirakan meningkat menjadi 29.120.000 lebih dengan umur harapan hidup 70 - 75 tahun.

\section{Meningkatnya umur harapan hidup dipengaruhi} oleh :

1. Majunya pelayanan kesehatan

2. Menurunnya angka kematian bayi dan anak

3. Perbaikan gizi dan sanitasi

4. Meningkatnya pengawasan terhadap penyakit infeksi

Secara individu, pada usia di atas 55 tahun terjadi proses penuaan secara alamiah. Hal tersebut akan dapat menimbulkan masalah fisik, mental, soaial, ekonomi, dan psikologis. Dengan bergesernya pola perekonomian dari pertanian ke industri, maka pola penyakit juga mengalami pergeseran dari penyakit menular menjadi penyakit tidak menular (degeneratif).

Survei rumah tangga pada tahun 1980, menunjukkan bahwa angka kesakitan penduduk usia lebih dari 55 tahun sebesar 25,70 \% diharapkan pada tahun 2000 nati angka tersebut akan mengalami penurunan menjadi 12,30 \% (Departemen Kesehatan RI, Pedoman Pembinaan Kesehatan Lanjut Usia Bagi Petugas Kesehatan I, 1992).

Penyebab kematian karena penyakit jantung , pembuluh darah (kardiovaskuler) dan Tuberkulosis, pada saat ini menduduki urutan pertama pada kelompok usia lanjut, selanjutnya kanker dan ketiga stoke ( $C V A)$. Kerja sama dengan lintas program dan lintas sektoral dalam pembinaan lanjut usia belum mantap, oleh karena itu peran serta masyarakat dalam pembinaan kesehatan lanjut usia perlu dikembangkan secara optimal.
Seperti dinyatakan dalam garis-garis Besar Haluan Negara, bahwa berhasilnya Pembangunan asional itu bergantung pada partisipasi seluruh rakyat serta sikap mental, tekat dan semangat, ketaatan dan disiplin para penyelenggara negara serta seluruh rakyat. Seluruh rakyat berarti baik yang muda maupun yang tua, remaja maupun lanjut usia, pria maupun wanita. Masing-masing berpartisipasi menurut bagian, tanggung jawab, dan kemampuan masing-masing.

Bila dilihat dari angka statistik pada saat sekarang ini, masalah lanjut usia belum menduduki hal yang sangat penting, tetapi berhasilnya pembangunan selama beberapa pelita ini menunjukkan bahwa angka harapan hidup bangsa Indonesia pada masa mendatang akan meningkat secara terus menerus sehingga pembinaan lanjut usia ini semakin menonjol peranannya. Hal tersebut tentunya memerlukan adanya kerja sama dengan lintas program dan lintas sektoral untuk pelayanan kesehatan usia lanjut yang mantap untuk menuju lanjut usia bahagia, berguna dan berkualitas serta perlu Gerontologi dan Geriatri dimasukkan dalam kurikulum pendidikan kesehatan.

\section{Latar belakang demografi}

Latar belakang demografi dapat dilihat pada tabel proyeksi kependudukan dunia pada tahun 1970 1985 - 2000, tabel penambahan penduduk tahun 1970 2000 "Persentase" , rasio reproduksi dan umur harapan hidup 1985-2000 (Variant Medium), dan angka harapan hidup di Indonesia.

Dengan demikian lapisan lanjut usia dalam struktur demografi Indonesia menjadi makin tebal, dan sebaliknya balita menjadi relatif makin sedikit. Dengan kata lain, timbul regenerasi yang dapat membawa akibat negatif. Proses ini tentunya berlangsung beberapa tahap yakni :

\section{Tahap. I}

Tahap ini timbul kesenjangan antara generasi (generation gap), karena golongan muda secara dinamis mengikuti kemajuan teknologi canggih, sedangkan golongan lansia tidak acuh, tetap tertinggal dan membiarkan golongan muda berjalan terus . Keadaan ini belum berbahaya.

\section{Tahap II}

Karena makin tebalnya lapisan lansia dan makin meningkatnya tingkat kesehatan, merekapun masih mampu mengimbangi golongan muda, dan menghendaki tetap pada jabatannya serta tidak mau digeser. Pada saat inilah timbul tekanan pada generasi muda (generation pressure), yang lebih berbahaya dari keadaan tahap I. Tahapan di Indonesia saat ini adalah tahap I, dan di sana sini mulai memasuki tahap II dengan timbulnya isu peningkatan usia pensiun (dari 55 tahun menjadi 60 tahun).

\section{Tahap III}


Adalah yang paling berbahaya, ditandai dengan timbulnya komflik antar generasi (generation conflict). Dalam keadaan ini para lansia yang jumlahnya makin banyak merasa makin kuat dan terus menerus menekan generasi dibawahnya. Sedangkan golongan muda terus bereaksi dan melawan tekanan-tekanan itu hingga timbul komflik yang berkepanjngan dan sulit diatasi dengan segera, keadaan ini bisa berbahaya.

\section{Konsep Dasar Medis Rheumatik}

1. Pengertian

Rheumatik adalah penyakit yang menyebabkan nyeri dan kaku pada sendi, otot dan tendon. Keadaan ini berlangsung selama beberapa hari atau beberapa tahun dapat menyebabkan gangguan atau cacat yang lebih parah. Penyakit rheumatic tidak menular, sebagian kecil dapat diturunkan namun sebagian besar tidak. Penyakit rheumatic tidak selalu memburuk hanya sedikit saja yang mengakibatkan kecacatan. Sebagian besar penderita tetap sehat, aktif dan berumur panjang dan tidak mengalami kesulitan sewaktu penyakit tidak aktif lagi. Kematian akibat penyakit rheumatic sangat jarang terjadi.

Meskipun penyakit yang tidak diketahui penyebabnya, umumnya rheumatic berhasil diterapi supportif dan resimen theraphy saat ini. Sebagian besar pasien penyakit rheumatic membaik dengan kombinasi istirahat, terapi fisik dan terapi obatobatan.

2. Etiologi

Beberapa penyakit rheumatic belum diketahui penyebabnya tetapi cara pencegahannya diketahui.. saat ini belum ada obat untuk menyembuhkan penyakit ini, namun demikian pengobatan dengan obat dapat meradakan nyeri dan mengendalikan penyakit. Adapun factor-faktor yang mempengaruhinya adalah sebagai berikut;

a. Mekanisme imunitas (antigen antibody)

b. Factor metabolic

c. Infeksi dengan kecenderungan virus

d. Proses degenerasi usia

e. Trauma berulang

f. Terdapat endapan Kristal dalam sendi

g. Kehamilan

3. Manifestasi klinik

a. Gejala setempat

1) Secara umum sakit persendian kuku dan pergerakan terbatas

2) Semua sendi dapat terserang seperti panggul, lutut, pergelangan tangan, siku, bahu dan rahang.

3) Lambat laun membengkak, panas dan merah

4) Perubahan bentuk tangan, jari bengkak seperti alat pemukul gendang, deformitas bentuk leher angsa dan jari serta ulna deviasi jari tangan.

b. Gejala sistemik
1) Capek
2) Lemah
3) Lesu
4) Anemia
5) Berat badan menurun
6) Takikardi
7) Demam

4. Penatalaksanaan medic

Keberhasilan dari pengobatan oenyakit rheumatic tidak terlepas dari peranan dari pada penderita itu sendiri.ntanpa kerjasama yang baik antara petugas kesehatan dan pasien maka pengobatan dengan sendirinya akan terhambat. Untuk memperlancar proses pengobatan maka diharapkan seorang penderita/pasien mampu menceritakan tentang:

a. Sifat, berat dan lokasi yang diderita

b. Sejak kapan keluhan ini dirasakan

c. Adakah factor pencetus kelainan seperti

kegemukan atau hal lain

d. Apakah penyakit ini terjadi secara tiba-tiba (akut) atau berkembang lambat.

e. Apa dan bagaimana aktifitas anda sehari-hari

f. Adakah kemungkinan penyakit ini diturunkan

Penatalaksanaan medic atau terapi yang dapat dilakukan pada penderita rheumatic antara lain:

a. Istirahat mutlak pada tingkat akut $2-4$ jam

b. Istirahat memakai bidai sendi seperti tongkat penyangga, kursi roda

c. Terapi fisik:

1) Bantu latihan secara aktif untuk menjaga fungsi

2) Kompres lembab hangat untuk reaksi otot dan mengurangi nyeri

3) Pembedahan bila perlu untuk direkonstruksi

d. Pemberian obat-obatan

\section{Metode Peneltian}

Dalam penulisan Karya Tulis Ilmiah ini menggunakan metode studi kasus untuk asuhan keperawatan, maka pendekatan yang digunakan adalah proses keperawatan mulai dari pengkajian, penyusunan diagnosa, perencanaan, tindakan dan evaluasi. Studi kepustakaan, mempelajari literatur yang berkaitan dengan atau relevan dengan isi studi kasus ini. Diskusi dengan perawat yang ada di ruangan, tenaga kesehatan yang terkait, dosen dan para pembimbing baik dari pihak institusi pendidikan maupun dari pihak Puskesmas.

\section{Pembahasan}

Setelah membahas konsep teori dan penerapan asuhan keperawatan Gerontik pada kasus nyata, pada bab ini penulis akan menguraikan kesenjangan kesenjangan yang di temukan antara konsep teori dengan penerapan praktek nyata. 
Untuk memudahkan dalam memahami kesenjangan yang ada di dalam teori dan kasus, penulis membahas sesuai dengan urutan proses keperawatan yaitu dimulai dari pengkajian, diagnosa keperawatan, perencanaan keperawatan, implementasi dan evaluasi. Untuk lebih jelasnya dapat diuraikan sebagai berikut :

\section{Pengkajian}

Data yang dapat dikemukakan dalam teori menurut (Dongoes, marylm E 2000) : nyeri sendi, nyeri tekan, kekakuan pada pagi hari, keletihan, keterbatasan rentang gerak, atrofi otot, kelainan pada sendi dan otot, sianosis, kemerahan pada jari, ketidakberdayaan. kesulitan mengunya, mual, kekeringan pada membrane mukosa, kesemutan pada tangan dan kaki, hilangnya sensasi pada jari tangan dan kaki, hilangnya sensasi pada jari tangan, pembengkakan pada sendi, isolasi.

Sedangkan hasil pengkajian yang dilakukan pada Tn. "S" didapatkan data yaitu: Pasien mengatakan nyeri pada tulang dan sendi, pasien megatakan nyeri dirasakan hilang timbul yang dialami sejak 4 tahun yang lalu, pasien juga mengatakan terjadi kekakuan pada sendi, ekspresi wajah pasien tampak meringis, tanda-tanda vital: TD: $140 / 90 \mathrm{mmHg}, \mathrm{N}: 84 \mathrm{x} /$ menit, $\mathrm{P}: 24 \mathrm{x} /$ menit, $\mathrm{S}: 36^{\circ} \mathrm{C}$, pasien juga mengeluh nyeri tekan pada lengan kanan, pasien juga cepat merasa lelah jika beraktivitas, skala nyeri 3 (ringan), terjadi kekakuan gerak,

Secara garis besar tampak adanya persamaan antara teori dengan manifestasi klinis yang ditemukan penulis pada tinjauan kasus. Walaupun demikian, ditemukan kesenjangan antara teori dengan kasus yaitu: Pada teori menurut Doengoes dia menemukan adanya mual, sianosis,kesemutan pada tangan dan kaki, hilangnya sensasi pada jari tangan dan kaki, hilangnya sensasi pada jari tangan, pembengkakan pada sendi, isolasi sedangkan pada Tn."S" tidak di temukan data-data tersebut ini terjadi karena kondisi pasien yang masih dalam keadaan belum parah. Ini juga disebabkan karena adanya sistem pertahanan tubuh setiap individu berbeda-beda sehingga respon terhadap penyakit pun berbeda-beda.

\section{Diagnosa Keperawatan}

Menurut (Doengoes,) diagnosa keperawatan yang sering muncul pada pasien dengan rheumatik ada 6 diagnosa keperawatan, sedangkan yang ditemukan hanya tiga diagnosa keperawatan. Diagnosa keperawatan yang ditemukan pada teori yaitu

a. Nyeri b/d distensi jaringan oleh akumulasi cairan/proses inflamasi, destriksi sendi.

b. Kerusakan mobilitas fisik b/d deformitas skeletal, nyeri, penurunan kekuatan otot.

c. Ganggauan citra tubuh b/d perubahan kemampuan untuk melakukan tugas-tugas umum. d. Kurang pengetahuan b/d keterbatasan kogmitif daya ingat.

e. Kurang perawatan diri b/d penurunan kekuatan, daya tahan, nyeri pada waktu bergerak.

f. Kurang pengetahuan tentang penyakit, prognosis, dan kebutuhan pengobatan b/d kurang terpajan informasi.

Sedangkan diagnosa keperawatan yang ditemukan dalam kasus yaitu:

1. Gangguan rasa nyaman / nyeri b/d penurunan fungsi tubuh

2. Hambatan / kerusakan mobilitas fisik b/d penurunan fungsi system muskuloskeletal

3. Resiko cerefisik b/d penurunan fungsi tubuh

Sebagian besar diagnosa yang terdapat dalam teori ditemukan dalam kasus. Walaupun demikian, masih terdapat kesenjangan antara diagnosa yang ada dalam teori dengan diagnosa pada kasus.

Diagnosa keperawatan yang ditemukan dalam kasus tetapi tidak ditemukan dalam teori yaitu : Risiko cedera fisik b/d penurunan fungsi tubuh. Hal ini muncul karena perubahan fungsi tubuh pasien yang telah lanjut usia dengan umur 67 tahun. Selain itu juga, hal ini terjadi karena saat penulis melakukan pengkajian, pasien mengatakan terjadi kekakuan pada sendi tulangnya.

Diagnosa yang tidak di dapatkan dalam kasus Tn."S" yaitu :

1. Ganggauan citra tubuh $b / d$ perubahan kemampuan untuk melakukan tugas-tugas umum.

2. Kurang pengetahuan $\mathrm{b} / \mathrm{d}$ keterbatasan kogmitif daya ingat.

3. Kurang perawatan diri b/d penurunan kekuatan, daya tahan, nyeri pada waktu bergerak.

4. Kurang pengetahuan tentang penyakit, prognosis, dan kebutuhan pengobatan $\mathrm{b} / \mathrm{d}$ kurang terpajan informasi.

Diagnosa tersebut diatas tidak diangkat sebagai masalah pada Tn."S" karena tidak adanya data yang mendukung diangnosa tersebut. Walaupun pasien mengalami kekakuan pada sendi tetapi dia masih mampu melakukan kegiatan sehari-harinya.

\section{Rencana Keperawatan}

Perencanaan keperawatan yang direncanakan sesuai diagnosa keperawatan pada kasus yaitu :

1. Gangguan rasa nyaman / nyeri b/d peningkatan tekanan serebral.

Intervensi keperawatan:

a. Kaji tingkat nyeri

b. Observasi tanda-tanda vital

c. Atur posisi senyaman mungkin

d. Ajarkan pasien relaksasi

e. Ajarkan kilen cara mengatasi nyeri dengan kompres air hangat. 
f. Anjurkan pasien rajin minum obat sesuai resep dokter

2. Gangguan mobilitas fisik $b / d$ penurunan fungsi

sistem muskuloskeletal

Intervensi Keperawatan:

a. Kaji kemampuan dan kelemahan secara fungsional .

b. Kaji derajat mobilisasi pasien dengan menggunakan skala ketergantungan (0-4) atau dengan skala tingkat kemandirian.( 0-5 ) atau ( A- E )

c. Jelaskan pada pasien tentang proses penuan dan mamfaat latihan bagi tubuh.

d. Ajarkan dan demons trasikan latihan ROM aktif/pasif

e. Ajarkan pasien teknik relaksasi.

f. Buatkan rencana aktivitas pasien sehingga istirahat pasien tidak terganggu

g. Beri kesempatan pasien utk melakukan akti vitas secara optimal sesuai kemampuan.

h. Anjurkan kelurga utk membantu pasien dalam aktivitas sehari - hari yang dirasa berat bagi pasien

i. Libatkan keluarga dalam kegiatan latihan dan aktivitas sehari - hari.

j. Lakukan kolaborasi dengan tim kesehatan lain bila ada keluhan.

3. Risiko cedera fisik berhubungan dengan penurunan fungsi persayarafan ditandai.

Intervensi Keperawatan:

a. Kaji tingkat penurunan fungsi persyarafan Tn."S".

b. Jelaskan pada klein tentang proses penuaan dan dampaknya pada syaraf.

c. Jelaskan kebutuhan Tn."S" akan keamanan dan keselamatan akibat penurunan fungsi tersebut.

d. Ciptakan lingkungan ruangan yang cukup:pencahayaannya, lantai tidak licin/basah dan ada pagar untuk berpegang tangan.

e. Hindari lantai kamar mandi dan WC yang licin serta beri pegangan.

f. Dekatkan barang -barang keperluan Tn."S".

g. Ajarkan cara menggunakan alat bantu pindah (turun dari tempat tidur, bangun pada malam hari untuk $\mathrm{BAB} / \mathrm{BAK}$.

h. Libatkan keluarga dan tetangga untuk saling tolong - menolong.

a. Kolaborasi dengan tiem kesehatan lain daalm hal pengobatan atau tindakan lainnya.

\section{Implementasi}

Pada pelaksanaan tindakan keperawatan disesuaikan dengan intervensi yang ada. Dalam melakukan tindakan keperawatan penulis bekerja sama dengan keluarga pasien dan pasien, dimana pasien sendiri sebagai objek. Selama pelaksanaan asuhan keperawatan penulis senantiasa memperhatikan aturanaturan dalam melaksanakan tindakan keperawatan.
Selain itu juga penulis mendapat banyak hambatan mulai pada awal pengkajian keperawatan sampai pelaksanaan implementasi yaitu masalah bahasa, tetapi itu tidak menjadi hambatan penulis untuk melakukan/melaksanakan asuhan keperawatan pada Tn."S".

\section{Evaluasi}

Evaluasi keperawatan antara teori dan kasus, mengacu pada kriteria tinjauan, evaluasi masalah keperawatan dilakukan melalui proses dengan melihat perkembangan respon pasien selama tiga hari. Evaluasi dilakukan setelah ada tindakan keperawatan yang diberikan kepada pasien. Dalam tahap evaluasi ini ketiga diagnosa yang ditemukan pada Tn."S" belum ada yang teratasi ini terjadi karena pasien masih mengeluh nyeri pada persendiannya, wajah pasien masih tampak meringis, kekakuan pada sendi dan tulang masih terjadi.

\section{Kesimpulan}

Berdasarkan pembahasan yang telah ditemukan, penulisan dapat menarik beberapa kesimpulan yaitu :

1. Pada pengkajian dengan rheumatik data yang ditemukan dalam tinjauan teori tidak ditemukan pada kasus yaitu : mual, sianosis, pembengkakan pada sendi, kesemutan pada tangan dan kaki, hilangnya sensasi pada jari tangan dan kaki, hilangnya sensasi pada jari tangan, pembengkakan pada sendi, isolasi.

2. Diagnosa keperawatan yang ditemukan dalam kasus ada yang tidak terdapat pada teori, Risiko cedera fisik b/d penurunan fungsi tubuh.

3. Pelaksanaan rencana asuhan keperawatan mencakup pada masalah keperawatan, yang muncul dengan berpedoman pada teori dan tetap memperhatikan kondisi pasien, fasilitas yang ada dan kebijaksanaan pihak Puskesmas Barombong Kecamatan Tamalate Kota Makassar.

4. Pada evaluasi keperawatan masalah Tn."S" belum ada yang teratasi karena pasien masih mengeluh nyeri pada persendian dan masih terjadi kekakuan pada tulang dan sendi. 


\section{Saran-Saran}

1. Pendidikan dan penyuluhan kesehatan perlu ditingkatkan dan dilaksanakan secara intensif pada seluruh komponen masyarakat, terutama pada usia lanjut karena sangat rentang terhadap berbagai jenis penyakit dalam hal ini penyakit Rheumatik, agar mereka dapat berperan aktif untuk memelihara dan meningkatkan derajat kesehatannya.

2. Rencana keperawatan yang telah dilaksanakan agar tetap menjadi program bagi keluarga Tn."S" dan mempertahankan apa yang telah didapatkan selama pelaksanaan asuhan keperawatan. Dalam pelaksanaan tindakan keperawatan hendaknya disesuaikan dengan situasi dan kondisi yang dimiliki oleh lansia.

3. Perlu adanya kerjasama yang baik antara keluarga lansia atau lansia itu sendiri dengan petugas kesehatan agar kasus penyakit yang dihadapi dapat ditangani secara kooperatif dan hasil yang didapatkan dari evaluasi sesuai dengan kriteria yang diharapkan.

4. Melihat waktu pelaksanaan perawatan pada pasien dan keluarga yang cukup singkat dan hasil dari implementasi keperawatan yang diberikan dapat terlihat secara menyeluruh maka diharapkan pada pihak terkait dalam hal ini pihak puskesmas dapat melanjutkan proses keperawatan yang telah diberikan untuk melihat evaluasi yang diberikan dan sekaligus menentukan tindak lanjut jika yang memang perlu.

\section{DAFTAR PUSTAKA}

Bambang Dwiloka, Rati Riana (2005), “Tehnik Menulis Karya Ilmiah", Rineka Cipta “ '-rta.

Brunner \& Suddarth, 2002, Ki ttan Medikal Bedah, Edisi 8, EGC, Jakarta.

Corwin Elizabeth. J, 2001; Buku Saku Patofisiologi ; EGC, Jakarta.

Kementerian Kesehatan, 2005, Profil Kesehatan Indonesia 2005, Jakarta.

Dinas Kesehatan Provinsi Sulawesi Selatan, 2017, Profil Kesehatan Sulawesi Selatan, 2017. Makassar

Dinas Kesehatan Sulawesi Selatan, 2017, Proporsi 10 Penyakit Tidak Menular di Sulawesi Selatan.Makassar

H. Slamet Suyono, (2001), Ilmu Penyakit Dalam, Edisi 3 Jilid 2, Balai Penerbit, FK UI, Jakarta.

Manjoer, Triyanti, 2001. Kapita Selekta Kedokteran, Edisi 3 Jilid 2, 2001.

Muh. Nazir, Ph.D, 2003, “Metode Penelitian”, Ghalia Indonesia, Jakarta.

Marliani Lili, Tantan S, 2007, “100 Question \& Answers: Hipertensi”, elexmedia komputindo, Jakarta.

Stein, Jay H, (2001); Panduan Klinik ilmu Pemyakit Dalam, Edisi 3, EGC,Jakarta.

Puskesmas Barombong, 2017, Hasil Pencatatan dan Pelaporan Kegiatan Kesehatan Lanjut Usia Puskesmas Barombong Kota Makassar. 